\title{
CÜZCÂN BEYLERİ: FERÎGÛNÎLER 250-401/864-1010
}

\section{JUZJAN RULERS: FARÎGHÛNIDS 250-401/864-1010}

\section{Mustafa AKKUŞ* İzetullah ZEKIं**}

Anahtar Kelimeler Cüzcân, Ferîgûnîler, Saffârîler, Gazneliler, Sâmânîler.

Keywords

Juzjan, Farîghûnids, Saffarid, Ghaznavid, Sâmânîd.

*Doç. Dr., Necmettin Erbakan Üniversitesi Sosyal ve Beşeri Bilimler Fakültesi Tarihi Bölümü akkus75@hotmail.com ORCID: 0000-0001-6327-8278 Konya/TÜRKIYE

**Doç. Dr., Burdur Mehmet Akif Ersoy Üniversitesi İlahiyat Fakültesi İslam Tarihi ve

Sanatları Bölümü izzetullahzeki@yahoo.com ORCID: 0000-0001-6571-7377 BURDUR/TÜRKIYE

Gönderim Tarihi: 24/01/2021 Kabul Tarihi: $08 / 06 / 2021$

\section{$\ddot{O} z$}

Ferîgûnîler, 278-401/892-1010 yılları arasında bugünkü Kuzey Afganistan'da bulunan Cüzcan'da hüküm süren yarı bağımsız bir Türk hanedanıdır. Sâmânîler ve Gaznelilerle siyasî ve ailevî ilişkiler kuran Ferîgûnîler, barış yanlısı tutumları ve akıllı siyasetleri sayesinde uzun bir süre bölgedeki mevcudiyetlerini korumayı başardılar. Ferîgûnîlerin sinırları kuzeyden Âmu Derya, güneyden Garcistân, Gûr ve Talikân'a kadar uzanmaktaydı. Gûr'da hüküm süren Gûr Şah, Ferîgûnîlere bağlıydı. Ferîgûn'un sülalesi hakkında bilinen yegâne bilgi Utbî'nin aktardığı hicri üçüncü asırda Ferîgûn Ribatı etrafında yaşayan hanedan olmalarıdır. Dönemin kaynaklarında hanedan emîri olarak yedi kişiden söz edilmekte olup 250/864 yllında hanedanın başında olan ve kurucusu olduğu düşünülen Ferîgûn hakkında fazla bilgi bulunmamaktadır.

Ferîgûn'un vefatından sonra oğlu Ahmed, 279-340/892-951 yilları arasında hanedanı idare etti. Ahmed, 287/900 yılında Saffârî Emiri Amr b. Leys tarafindan Sâmânî Hükümdarı İsmail'e karşı set oluşturmak üzere Belh'e vali olarak gönderildi. Hanedanın üçüncü emiri Ebü'l-Hâris Muhammed $b$. Ahmed'dir. Illim ve ulemayı seven bir emir olan Ebü'l-Hâris Muhammed'e 372/982 yılında anonim "Hudûdü'l-Âlem mine'l-Maşrik-i ile'l-Mağrib" adlı eser takdim edildi. Gaznelilerle iyi münasebetleri olan Ebü'l-Hâris Muhammed'in ardindan Ebü'l-Hâris Ahmed b. Muhammed ve Ferîgûn $b$. Muhammed geçti. Uzun sürmeyen Ferîgûn'un döneminden sonra aynı yıl içinde kardeşi Ebû Nasr Muhammed b. Ebü'l-Hâris Muhammed b. Ahmed b. Ferîgûn, yönetimin başına geçerek Gaznelilerle ailevî ve dostane ilişkilerini sürdürdü. Ferîgûnîlerin son emiri 399/1008 yılında Gazneli Mahmud'la

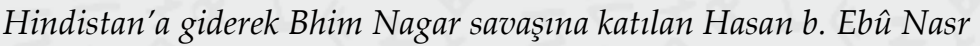
Ahmed'dir. Ferîgûnîler barıs yanlısı, ilim ve ulemayı himaye eden bir hanedandi. Hanedan mensupları ulema ile istişare eder, meclislerinde edip ve şairlere yer verir, onlarla sohbet etmekten haz duyarlardı. Onlar halka karşı adaletli tutumları ve hüsnü muameleleriyle hakl bir şöhret kazandılar. Şair

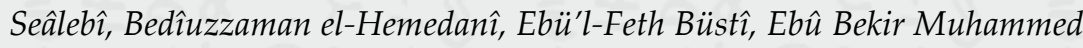
b. Abbas Hârizmî, Ebû Nasr Abdülcebbar Utbî gibi ulemanın eserlerinde Ferîgûnîlerden övgüyle bahsettikleri görülmektedir. Ayrıca bu çalışmada Ferîgûnîlerin Türk bölgesi Türkistan'ın yerli Türk halkından oldukları üzerine durulmuştur. Temel kaynakların aksine bazı muasır Iranlı araştırmacıların duygusallıkla Ferîgûnîlerin Fars olarak tanıtmalarının herhangi bir dayană̆ının olmadığı tespit edilmiştir. Hanedan emirlerinin sayısı ve sırası çalışmanın ikinci sorunu olarak görülmüş, toplamda yedi emirin hanedanın başına geldikleri kanaati ortaya koyulmuştur. 


\section{Abstract}

Farîghûnids is a semi-independent Turkish dynasty that ruled in Juzjan located in the north of today's Afghanistan, between 278-401 and 892-1010. They established political and familial relations with the Sâmânîd and Ghaznavids, and also managed to maintain their presence in the region for a long time thanks to their peaceful and intelligent behavior. The borders of the Farîghinids extended from the north to Âmu Darya, from the south to Garjistan, Gur and Talikan. Ghur Shah, who ruled in Gur, was subordinate to the Ali-i Farîghûn. The only known information about the family of Farîghun's is that the dynasty that lived around Ribat of Farîghûn in the third century reported by Utbi. In the sources of the period, six people are mentioned as the amirs of the family. At the beginning of the dynasty, Farîghun was the founder of the dynasty in 250/864, but there is not much information about him.

After Farîghûn's death, his son Ahmad ruled the dynasty between 279-340 and 892-951. He was sent by Seffarid Amir Amr b. Lays as governor to Belh to set up a barrier against the Sâmânî Amir İsmail. The third Emir of the dynasty, Abu'l-Hâret Mohammad b. Ahmad. An anonymous work titled Hududu'l-Âlam mine'l-Mashrik-i ile'l-Maghrib was presented to Abu'lHâret Muhammed, an emir who favored science and ulama. After Abu'lHâret Mohammad, who had good relations with the Ghaznavids, Abu'l-Hâret Ahmed b. Mohammed and Ferîgûn b. Mohammad passed. After the period of Ferîgûn which did not last long in the same year, his brother Abu Nasr Mohammad b. Abu'l-Hâret Mohammad b. Ahmad b. Farîghûn took over the administration and maintained familial and friendly relations with the Ghaznavids, the last emir of the Farîghûnîds, Hasan b. Abu Nasr Ahmed. The Farîghunids dynasty was a peace-loving and scholarly dynasty. Members of the dynasty would consult with the ulama and chat with writers and poets.

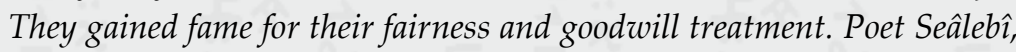
Badiuzzaman el-Hamadanî, Abul-Fath Bustî, Abu Bakir Muhammad Abbas Khârizmî and Abu Nasr Abduljabbar Utbî, Farighunid swere praised. In addition, in this study, it has been emphasized that the Farîghûnids are from the indigenous Turkish people of the Turkish region of Turkistan. Contrary to the basic sources, it has been determined that some contemporary Iranian researchers have no basis for emotionally describing the Farsi as Persian. The number and order of the dynasty orders were seen as the second problem of the study, and it was concluded that seven orders in total were the head of the dynasty. 


\section{GíRiş}

\section{Kavramsal Kargaşa ve Aydınlatılması}

Âl-i Ferûgûn (آل فريغون) olarak bilinen Ferîgûnîler, 279/892-401/1010 y1lları arasında hüküm süren, Ambâr, Şibirgân ve Fâryâb bölgelerini kapsayan Cüzcân merkezli yarı bağımsız bir Horasan beyliğidir (Gubar, 2005, s. 105; Hüseynî, 2020, s. 11). Emirleri sırasiyla Saffârîler, Sâmânîler ve Gaznelilere tabiydiler (Gubar, 2005, s. 105). En çok Gaznelilerle ailevî ilişkiler kuran Ferîgûnîler hanedanı Gazneli Mahmud tarafından sona erdirilerek, hâkim oldukları alanlar Gazneli topraklarına ilhak edilmiştir. Tarihi kaynaklarda Ferîgûn kavramının bugünkü Kuzey Afganistan dâhil, Hârizm ve Mâverâünnehir'e kadar uzanan büyük bir coğrafya için kullanıldığı, söz konusu bölgelerin Türklerin yoğun yaşadıkları Türkistan'ın güneyi olduğu aşikârdır. Fakat buna rağmen Leyla Şah Hüseynî gibi bazı muasır İranlı araştırmacılar, zorlama yorumlar yaparak Ferîgûnîlerin köklerini İran'a ve eski İran krallarından Ferîdûn'a nispet ettirmeye çalışmışlardır. ${ }^{1}$ Bunu da Hudûdü'l-Âlem mine'l-Maşrik ile'lMağrib adlı eserde geçen (Evlâd-ı Aferîdûn اولاد افريدون ) tabirine dayandırmışlardır (Hudûdü'l-Âlem, 1999, s. 76). Hâlbuki eserde ve diğer çalışmalarda bahsi geçen (Evlâd-1 Afrîdûn اولاد افريدون) veya (Evläd-1 Ferîgûn اولاد فريغون) cülesinden kastedilen Cüzcân emirleridir (Hudûdü'l-Âlem, 1999, s. 76; Müverrihü'l-Mısrî, 2209, s. 2). Nitekim Dönemin tarihçisi Utbî, bunun bir benzetme olduğuna işaret ederek Ferîgûnîlerin izzet, şeref ve yüceliklerini (Aferîdun فريدون)'a benzetmektedir (Utbî, 1996, s. 369). İbn Haldun ve Osmanlı tarihçisi Ağa Paşa da Cüzcân Emirlerinden (Benî Ferîgûn بني فريغون) olarak bahsetmişlerdir (İbn Haldun, 2000, s. 484; Ağa Paşa, 1909, s. 211). Dolaysıyla söz konusu ifadeyi esas alarak Ferîgûnîlerin Feridun'un soyundan geldiği iddialarda bulunmaları pek kuvvetli ve tutarlı görülmektedir. Burada kastedilen İbn Haldun'ın da işaret etiği (Benî Ferîgûn بني فريغون) dur.

Âl-i Ferîgûn ile ilgili en ayrıntılı bilgileri sunan ve döneme bizzat şahit olan muasır tarihçiler Utbî, Gerdîzî ve Beyhakî'dir. Utbî, eserinde (Zikr-i Âl-i Ferîgûn ذكر آل فريغون) diye müstakil bir başlık altında Ferîgûnîlerden bahsederek, onların Sâmânîler döneminde Cüzcân'a hâkim olduklarını dile getirir. Cüzcân'ı baba ve ecdatlarından miras aldıklarını, ilim, irfan ve dirayetleriyle bölgede hâkimiyet tesis ederek hanedanlıklarını koruduklarını aktarır. Daha çok Ferîgûnîlerin ilim ve marifet sahibi kimselerle yakınlıkları üzerine duran Utbî, Gazneli Mahmud'un babası Emir Nâsırüddin Sebük Tegin tarafından, Ebü'l-Hâris Ahmed b. Muhammed'in kızıyla evlendirildiğini ve Ebü'l-Hâris'in de oğlu Ebû Nasr'ı, Sebük Tegin'in kızıyla evlendirdiğini zikreder (Utbî, 1996, s. 294). Utbî, Ferîgûnîleri, anlatırken onların

Leyla Şah Hüseynî, "Ferîgûnîlerin Siyasi ve Kültürel Coğrafyası" Hüseyinî, başlı̆̆ı altında bağımsız bir çalışma yapan İranlı araştırmacıdır. Temel kaynakların aksine Horasan ve Horasan bölgesindeki Türk, Tacik, Afgan ve Farsların hepsini İranlı hanedanlar olarak yorumladığı, söz konusu beyliklerin menşeini de İran krallarına nispet ettirdiği görülmüştür. Ana kaynaklarda bahsi geçen Ferîgûnîlerle ilgili bilgilerin çarpıtıldığı, milliyetçilik harsıyla duygusallığa kapılarak yanlış aktarılmıştır.(Hüseynî, 2020, s. 11) 
kökenleri hakkında herhangi bir bilgi vermezken, ilim ehli bir hanedan olduğunu ve Gaznelilerle ailevi münasebetleri bulunduğunu nakleder (Utbî, 1996, s. 294).

Utbî, Gerdîzî ve Beyhakî gibi tarihçiler ile Hudûdü'l-Âlem mine'l-Maşrik-i ile'l-Mağrib adlı eserin müellifinin aktardığı bilgileri günümüz İranlı araştırmacılar kasıtlı bir şekilde Ferîgûnîlerin atası Ferîgûn'u eski İran krallarından Feridun'un torunu olduğunu ileri sürmüşlerdir (Davud, Farîghûnids" Encyclopaedia Islamica Online, Brill). Bunların kaynaklarından istifade eden batılı araştırmacı Bosworth da aynı fikri ileri sürdügü görülmektedir (Bosworth, 1984, s. 756). Ancak gerek tarih kaynakları, gerek coğrafi bilgiler ve gerekse mensup oldukları din ve mezhebe bakıldığında Ferîgûnîlerin tıpkı Gazneliler gibi Türk ve Sünnî Müslüman oldukları görülmektedir (Hudüd̂̂'l-Âlem, 1999, s. 73). Malum olduğu üzere Gazne, Buhara, Kaşgar, Belh, Cüzcan ve Herat gibi bilim ve sanat şehirleri Ehl-i Sünnete mensup Karahanlılar, Sâmânîler, Gazneliler, Selçuklular ve Timurluların yurdu olup, İran'a aidiyeti iddiası ve Farslıların yaşadığı bir bölge olarak gösterilmesi doğru değildir. Nitekim Hudûdü'lÂlem adlı anonim eser bölgenin Türk yurdu olduğunu vurgulamakta ve Horasan'dan

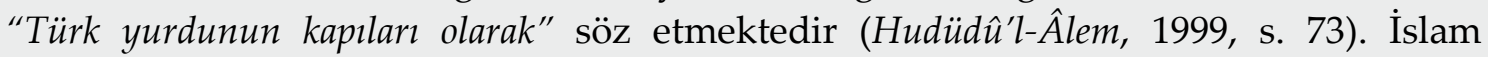
fetihleri sürecinde olduğu gibi günümüzde de Cüzcân başta olmak üzere söz konusu bölgelerde yoğun olarak Türklerin yaşamakta olduklarını belirtmekte fayda vardır. Buna örnek olarak bölgedeki Müslüman Araplarla Türkler arasındaki çetin çatışmalarla, Kuteybe b. Müslim'in valiliği döneminde yaşanan mücadeleler örnek verilebilir (Âmini, 2009, s. 11; Kitapçı, 2000, s. 249).

Hudûdü'l-Âlem'deki bilgilerin yanlış yorumlanması, (Ferîgûn فريغون) kavramı ile hiçbir alakası olmayan "Feridun'a فريدون" nispet edilmesi konuyu tartışmalı bir hale getirmiştir. Ayrıca eserin Ferîgûnî hanedanına mensup birinin (ابن فريغون İbn Ferîgûn) tarafından kaleme alındığı rivayetini göz önünde bulundurduğumuzda (Bosworth, 1999, s. 19) kendi atalarından Ferîgûn'a işaret ederek (Evlâd-1 Ferîgûn اولاد فريغون) şeklinde övgüyle nakletmiş olması, Feridun'a hiç değinmemesi bu iddiaların mesnetsiz olduğunun da delilidir. Zira Fars asıllı bir hanedan olsalardı muhtemelen Feridun gibi İran'ın milli kahramanından sitayişle bahsedileceği ve nesep ilişkilerini ortaya koymaktan kaçınmayacağı aşikârdır.

Tarihi kaynaklarda belirtildiğine göre Ferîgûn, Cüzcân, Hârizm ve Mâverâünnehir bölgelerinde maruf, meşhur ve revaçta olan bir kavramdı. İranlı araştırmacıların Hudûdül-Âlem'de nakledilen (Evlâd-1 Ferîgûn اولاد فريغون) cümlesini (İran kralı Feridun'un evladı) şeklinde yorumlamaları Batılı araştırmacıların da aynı hataya düşmelerine sebep olmuştur. Buna binaen Cüzcân Ferîgûnîleri ile Pers İmparatorluğundan 995 yılına kadar Hârizm’ de hüküm süren (Âl-i Aferîğ آل افريغ، آل كاث (آل عراق arasında bir ilişkinin olduğu dile getirilmiştir (Haug, "Farîghûnis", Encyclopaedia of Islam, Brill, 2015). Batılı araştırmacı Bosworth'un eserine bakıldığın da Cüzcân Ferîgûnîleri ile Afrigoğullarının ayrı hanedanlar olup Sâmânîlere bağlı Araplar ve İranlılara nispet edildikleri görülmektedir (Bosworth, 1999, s. 28). Âl-i Kas, Âl-i Irak olarak da bilinen Âl-i Afrig, 995 yılına kadar varlığını sürdüren, geçmişlerini Keyhüsrev'e ulaştıran tamamen farklı bir hanedandır(Hümayun, 2004, s. 43). Dönemi ve olayları göz önüne aldığında Afrigoulları ile Ferîgûnîlerin farklı hanedanlar oldukları kanaati hâsıl olmaktadır. Çünkü Hârizm'daki Âl-i Afrîg ile Cüzcan'daki Âl-i 
Ferîgun'un aynı sülaleden oldukları veya ailevi ilişkileri oldukları hakkında herhangi bir bilgi bulunmamaktadır.

Dönemin bazı tarihçileriyle modern araştırmacılar, Cüzcân Ferîgûnîlerini 995-1017 yıllarında Hârizm'de hüküm süren Me'mûnîlerin devamı olduğu üzerine durmuşlardır. Bu görüşte olanların yanılmalarının bazı sebepleri bulunmaktadır. Bosworth'un yanıldığı nokta İranlı araştırmacılara dayandırdığı, Cüzcân Ferîgûnîleri ile Hârizm Afrigoğulları'nın adlarındaki isim benzerliğinden dolayı İran'a nispet etmesidir (Bosworth, 1999, s. 28). Hâlbuki her açıdan (Feridun فريدون) ve (Ferîgûn فريغون) farklı bir isimdir. Zikrolunduğu üzere Afrigoğullar'nın Hârizm hâkimiyetleri 995 yılında sona ermiş, Me'mûnîler dönemi başlamıştır. Afrigoğulları ile Ferîgûnîleri aynı hanedan sayanların yanıldıkları ikinci nokta ise isim ve vaka benzerliğinden kaynaklanan eserlerdeki hatalardır. Mesela Müstevfî, Me'mûnîler'den bahsederken tırnak içinde Ferîgûnîler olarak söz etmektedir. Müstevfî'nin işaret ettiği nokta Me'mûnîler'den önce bölgede hüküm süren Afrigoğulları'dır (Müstevfî, 1961, s. 397). Onun niyeti veya kastı Cüzcân Ferîgûnîleri değildir. Tarihçilerin söz konusu hanedanları karıştırarak ilişkilendirmelerinin bir sebebi de Gazneli Mahmud başta olmak üzere Gaznelilerın Hârizm ve Cüzcân bölgelerindeki hanedanlarla ailevi ilişkiler kurmaları ve onları itaatleri altına almalarından kaynaklanmış olmalıdır. Ayrıca her iki hanedanın (Afrigoğulları ve Me'mûnîleri) yönetim merkezleri Ceyhun nehri bölgesidir. Hârizm'de hüküm süren Afrigoğulları ve Me'mûnîleri'nin merkezi Ceyhun Nehri'nin batı tarafında yer alan Gürgenc (Urgenç, Cürcâniye), günümüz Özbekistan topraklarında bulunan Hive bölgesidir (Hudüdû'l-Âlem, 1999, s. 35) . Cüzcân Ferîgûnîlerin merkezi ise günümüz Afganistan topraklarında bulunan Anbâr ve Şibirgân bölgeleridir (Müstevfî, 1961, s. 397).

Hanedanın kökeni hakkındaki tartışmaya yol açan nokta anlaşıldığı üzere kavram ve ses bezerliğidir. Kanaatimize göre İran kralı (Ferîdûn فريدون), Cüzcân Emirlerinin atas1 (Ferîgûn فريغون), Hârizm'de hüküm süren (Afrîğ, Âl-i Afriğg فريغ، آل الفريغ), Fergâne'ye mensup (Fergânîler فرغانيلر) tamamen farklı kavramlar olup farklı zamanlarda yaşayan farklı kişi ve hanedanlardır. Bu ihtilafa yol açan temel sorunlardan biri de hanedan hakkındaki kaynak yetersizliğidir. Çalışma sırasında hanedanın biyografik ve kronolojik tarihini anlatan herhangi bir temel kaynağa ulaşılmamıştır. En fazla bilgiyi Gazneli tarihini ele alan Utbî, Beyhakî, Gerdîzî'nin verdiği, coğrafi bilgiler içeren Hamevî, İbn Havkal, Makdisî ve Hudûdü'l-Âlem'nin yüzeysel olarak sadece Cüzcân'ın coğrafyası hakkında bilgi sundukları görülmüştür. Farsçada 2014 yılında İranlı Leyla Şah Hüseynî'nin "Ferîgûnîlerin Siyasi Coğrafyası" hakkında bir yüksek lisans tezi yazarak daha sonra kitap haline getirdiği, temel kaynaklardaki bilgilerin duygusallıkla ele alarak Ferîgûnîlerin İran kökenli olduğunu vurguladığı tespit edilmiştir. Diğer bir İranlı araştırmacı Türkçede Ferîguîler hakkında iki paragraflık Diyanet İslam Ansiklopedisindeki madde dışında hiçbir bağımsız çalışmanın yapılmadığı, söz konusunu maddenin modern Farsça çalışmaların gölgesinde kaldığı görülmüştür. Günümüzde Arapçada hiçbir çalışmaya rastlanmayan Ferîgûnîler hakkında batılı araştırmacı Bosworth'un 1984 yılında Encyclopaedia Iranica' da "Âl-i Ferîgûn" başlığı altında dört sayfalık bir madde yazmıştır. Ayrıca Seyyed Ali Davud'un 2018 yılında "Âl-i Ferîgûn" başlığı altındaki çalışması 
Encyclopaedia Islamica'da yayınlanmıştır. Dunlop'un 1991 yılında The Encyclopaedia of Islam' da "Farighunids" başlığıyla, Haarmann ve Ulrich'in 1996 yılında Islamic History and Civilization: Studies and Texts'te "Farîghunids" başlığı ile yazdıkları maddeler neşredilmiştir. Haug Robert'in 2015 yılında Encyclopaedia of Islam'da "Farighunids" başlıklı bir madde yazdığı tespit edilmiştir.

\section{FERÎGÛNî HANEDANININ İDARE MERKEZİ CÜZCÂN VE KONUMU}

İslam tarihinde Güzgânân, Cüzcânân ve Cüzcân olarak bilinen Cüzcân (جُوزجان), 33/653 yılında Ahnef b. Kays liderliğinde Emir Akra' b. Hâbis tarafından fethedilmiştir (Hamevî, 1977, 182; Yazıc1, 96)Taberî'nin naklettiğine göre Kuteybe b. Müslim, 91/709 yılında Horasan valiliği sırasında Cüzcân'a girmiş, Cüzcân Emiri dağlara çekilirken halk direniş göstermemiş, Kuteybe'de şiddete başvurmamış ve Cüzcân halkına dokunmamıştır (Taberî, 1967, s. 455). Ancak 97/715 yılında Emevîlerin Horasan valisi olarak Yezîd b. Mühelleb'in atanmasıyla bölge Emevîlerin iç hesaplaşmasına sahne olmuş, bölge halkı her yönden büyük sıkıntılar çekmiştir (Gerdîzî, 1949, s. 251; Hatîb, 1959, s. 31). Yezîd b. Mühelleb'in bölgedeki faaliyetleri halkın irtidadına sebep olmuş, bunun üzerine Yezîd, ordu toplayarak yeniden Cüzcân'a yönelmiş, halkın bir kısmı firar etmeyi başardıysa da on iki bin kişi ölümden kurtulamamıştır² (Gerdîzî, 1949, s. 251). Yezid bölgeye tamamen hâkim olmuş, ele geçirdiği Cüzcân'in emiri Sûl'un Müslüman olmasıyla da bölge Mesleme b. Abdülmelik dönemine kadar Emevî Hilafetinin idaresinde kalmıştır³ ${ }^{3}$ Gerdîzî, 1949, s. 252). Emevîlerin son dönemlerinde bölgede bazı huzursuzluklar yaşanmış, 119/737 yılında Cüzcân'ın Şübûrkân (Şibirgân) bölgesinde Türk hakanı ile Emevîler arasında Emevîlerin galibiyeti ile sonuçlanan bir savaş yaşanmıştır. Ayrıca 125/743 yılında Emevî yönetimine karşı çıkan Ali evladından Yahya b. Zeyd bu bölgede öldürülmüştür (Hamevî, 1977, s. 182; Yazıc1, 1993, 96). Bölgenin İslam topraklarına dâhil olmasıyla Cüzcân, Emevîler ve Abbâsîler tarafından Horasan'a gönderilen valileri tarafından yönetilmiştir. Ferîgûnîlere kadar geçen dönemi valiler ve beylikler (hanedanlar) dönemi olarak ikiye ayırabiliriz. 621-821 arasını kapsayan valiler döneminde 5'i Hulefây-i Râşidîn dönemi, 23'ü Emevîler

2 Bu olaylar hakkında ayrıntılı bilgiler veren Gerdîzî, Yezîd b. Mühelleb'in, Cüzcân halkının kanından değirmen döndürüp un yaparak öğle yemeği yemeden dönmeyeceğine dair yemin ettiğini, Cüzcân'1 ele geçirince de aynen dediğini yaptığını, insanların kanı kokmaya başlayınca üzerine su dökmeyi emrederek böylelikle değirmeni döndürerek un yaptırdığını elde ettiği undan ekmek pişirterek yediği ve bu şekilde ettiği yeminini yerine getirmiş olduğunu zikreder. Ayrıca altı bin kişiyi köle alarak köle pazarlarında satarak, Süleyman b. Abdülmelik'e Cüzcân'in fethini hakkında"Bu şehri Gahşapur Züleknaf'tan kimse alamamıştı. Hürmüz'ün oğlu Kisra ve Hattab'ın oğlu Ömer'in yüzüne kapatılmıştı. Kimsenin fethedemediği şehir Emirü'l-Müminin adına fethedilmiş oldu"diyerek övünç dolu bir mektup yazdığını aktarır (Gerdîzî, 1985, s. 251).

3 Gerdîzî Cüzcân emiri Sûl'un Müslüman oluşu hakkında şu hikâyeyi anlatır: “... Esir edilen Sûl, Yezîd b. Mühelleb'e: "Senden daha büyük zat yok ki elinde Müslüman olayım" dedi. Buna karşı Yezîd: "Emirü'lMüminin benden daha büyüktür" dedi. Bunun üzerine Sûl: "Beni onun huzuruna gönder!" dedi. Yezîd b. Mühelleb de onu Halife Süleyman b. Abdülmelik'e gönderdi. Süleyman'ın huzuruna giden Sûl: "Müslüman olmam konusunda senden daha büyük kimse yoktur" dedi. Halife Süleyman ise: "Bu gün Peygamberin mezarı hariç Müslümanlık konusunda benden daha büyük kimse yoktur" dedi. Sûl ise: "Beni oraya gönder ki Müslüman olayım" dedi. Bunun üzerine Halife Süleyman b. Abdülmelik onu Medine'ye gönderdi. Peygamber (s.a.v.)'in mezarının başında Müslüman olduktan sonra Yezîd'in yanına döndü" (Gerdîzî, 1985, s. 252). 
dönemi ve 20'si Abbâsîler döneminde olmak üzere toplamda 48 vali Horasan'a gönderilmiştir (Gerdîzî, 1949, s. 227; Zeki, Valiler, 2020, s. 26). Ferîgûnîlerin başlangıç ve gelişme dönemlerinde Horasan'da Tâhirîler, Saffârîlerler ve Sâmânîler egemen olmuşlardır (Gerdîzî, 1949, s. 313; Zeki, Hâkimiyet, 2020, s. 11). Önceleri Saffârîlerler ve Sâmânîlere bağlı bir yönetim olan Ferîgûnîler, 384/994 yılında Ebü'l-Hâris Muhammed liderliğinde Sebük Tegin ve Gazneli Mahmud'la yakınlaşmışlardır. Aynı zamanda Gaznelilerle ailevi ilişkiler kuran Ferîgûnîler, Sebük Tegin'in istediği zaman yardımlarına koşturmuşlardır (Utbî, 1966, s. 118).

Cüzcân'ın coğrafi kapsamı ve yönetim merkezi hakkında farklı görüşler bulunmaktadır (Gerdîzî, 1949, s. 373). Bu konuda fikir belirten önemli tarihçi ve coğrafyacıların başında Yakût el-Hamevî gelmektedir. O, 279/892 yılında kaleme aldığ Mucemü'l-Büldân adlı eserinde günümüzde Ser-i Pûl olarak bilinen Anbâr ile Fâryâb'ın Cüzcân'ın büyük beldelerinden olduğunu, el-Yahudiyye adlı büyük bir kasabasının da olduğunu nakletmiştir (Hamevî, 1977, s. 182). Hudûdü'l-Âlem, Cüzcân'nın sınırlarını doğudan Belh, Bamyan ve Toharistân'a; güneyden Gûr ve Büst'e, batıdan Garcistân'a ve Merv sınırlarına; kuzeyden ise Ceyhun sınırlarına kadar uzandığını nakletmiştir. Rebûşarân, Dermeşân, Tamrân, Tamazân, Sarvân, Manşân, Talikân, Cuhûdân, Fâryâb, Naryân, Gürzüvân, Kenderm ve Ebnir'i Cüzcân'in nahiyeleri olduğunu ilave etmiş, Cuhûdân'ın (Yahudân) Ferîgûnî yöneticilerin başkenti olduğunu zikretmiştir (Hudûdü'l-Âlem, 1999, s. 76).

Cüzcân'ın nahiyelerinden olan Rebûşarân, verimli ve geniş bir coğrafyadır. İnsanları cesur ve iyi savaşçıdır. Coğrafyası Garcistân'a kadar uzanan Rebûşarân'ın bir bölümünden Rey nehri geçmektedir. İçinde altın madenleri olan Rebûşarân'ın melikleri Cüzcân'a bağlı olup yıllık vergi verirler. Dermeşân'ın iki bölgesi olup biri Büst'e diğer ise Cüzcân'a bağlıdır. Bölgenin Nehri, Mevr nehrine bağlanan Dermeşân'ın melikleri Dermeşi Şah olarak adlandırılmaktadır. Tamrân ve Tamazân iki bölge olup Kervan Ribat'ına bitişik olup dağlarla sarılıdır. Sarvân, dağlar arasında kalan bir bölge olup halkı yaramaz, savaşçı, hırsız ve vefasızdır. Aralarında asabiyet yaygindır (Hudûdü'l-Âlem, 1983, s. 95).

Etrafı dağlarla sarılı Manşân'ın meliklerine Berazbende deniliyordu. Bölge halkı hayvancılık ile uğraşan dürüst insanlardı. Bunlar Cüzcân Emirlerine bağlı olup vergiye tabiydiler. Dağlarında altın, gümüş, bakır, sürme taşları ve demir madenleri bulunan Manşân, müreffeh bir nahiyeler arasındadır (Hudûdü'l-Âlem, 1983, s. 96). Bolca nimetleri olan Talikân, Cüzcân'ın sınırlarında olup nebiz (üzüm suyu) ile meşhurdu. Cuhûdan bölgesi, dağların eteğinde olup Cüzcân meliklerinin konaklama bölgesi olarak bilinirdi. Hoş ve temiz havası olan Cuhûdan gelişmiş bir nahiyeydi. Fâryâb, arasından kervan geçen gelişmiş bir bölgedir. Naryân, Fâryâb ile Cuhûdan arasında iki fersah genişlikte bir nahiyedir. Gürzüvân, dağlar arasında kalan, havası temiz, Cüzcân Emirlerinin eski yurdudur. Güzel nimetleri olan Kenderm, Nebiz (üzüm suyu, hurma şarabı) ile meşhurdu. Anbir, Cüzcân'ın ticaret merkezi kasabasıdır. Burada pazar ve fuarı açılır, deri ürünleri dünyaya ihraç edilirdi. Belh'in deposu olarak bilinen dağların eteğinde bulunuyordu (Hudûdü'l-Âlem, 1983, s. 97).

Cüzcân'ın Kular bölgesi, sulu, ağaçlı, yeşil ve gelişmiş bir bölgeydi. Şubûrkân, kervan yolu üzerine olup nimetleri boldu. İçinden nehir geçen Şubûrkân dağları 
arasında kalmıştı. Entuhz, dağlar arasında kalan verimsiz bir bölgedir. Sân, koyunun bolca yetiştiği bir nahiyedir. Ribat-1 Kervan, Cüzcân sınırlarında olup dağların arasında altın madenleri bulunurdu. Sengbun, üzerine minare ve kule yapılan bölgeydi. Ezyu, Cüzcân sınırlarının bittiği uç bölgedir (Hudûdü'l-Âlem, 1983, s. 98).

İbn Havkal, Hudûdü'l-Âlem'den önce kaleme aldığı eserinde Anbâr'1 bölgenin en büyük nahiyesi olarak zikretmekte ve Ferîgûnî emirlerin kış mevsimini burada, yazı ise iki dağ arasında kalan Cüzcân'da geçirdiklerini yazmaktadır. O, iki dağ arasında kalması hasebiyle Cüzcân'ı, Mekke'ye, halkını da Mekke halkına benzetmektedir (İbn Havkal, 1938, s. 443). Şubûrkân'1(Şibirgân), içinde nehir akan bir şehir olarak tavsif ederken, şehir halkı genellikle tarımla uğraştığını, bostanların azlığı, aksine meyvelerinin bol ve lezzetli olduğunu anlatmaktadır. Şubûrkân'1, Kenderm ve San'dan büyük olduğunu, büyüklük açısından el-Yahudiyye'e daha yakın olduğunu yazmaktadır (İbn Havkal, 1938, s. 443). San, Andhoy, Gürzüvân, Fâryâb, Nuyân, Şubûrkân (Şibirgân) Kenderm, el-Yahudiyye, Talikân ve Anbâr'ı Cüzcân'ın nahiyeleri olarak kaydetmektedir (İbn Havkal, 1938, s. 426). Anbâr'dan meyve bahçeleriyle suyu bol bir bölge olarak söz etmektedir. Küçük bir şehir olan Andhoy yedi köy ve birkaç Kürt ailenin evinden oluşmaktadır. Ayrıca İbn Havkal bölge halkının deve ve koyunla uğraştığı ve dericilik yaptıklarını rivayet etmektedir (İbn Havkal, 1938, s. 443).

Makdisî ise Hudûdü'l-Âlem gibi az bir nüfusa sahip olan Yahûdiye'nin Cüzcân'ın başkenti olduğunu nakletmekte, Anbâr, Fâryâb, Kâlân ve Şurkân (Şubûrkân, Şibirgân)'i de nahiyeler arasında saymaktadır. Başkent Yahûdiye'nin yolunun Ferîgûn Ribat'ına kadar dört bölümden oluştuğunu yazmaktadır. Ayrıca bölge halkının diyanet, dirayet, sahavet ve ilminin azlığını dile getirmektedir (Makdisî, 1991, s. 398). Hudûdü'l-Âlem bu Ribat'tan Cüzcân sınırlarında dağların arasında bulunan altın madeni olarak söz etmektedir (Hudûdü'l-Âlem, 1999, 78).

\section{CÜZCÂN EMIRLERİ: FERÎGÛNÎLER}

Ferîgûnî hanedanının başlangıcı ve kuruluş zamanı hakkında kesin bir bilgi yoktur. Ailenin başına gelip geçen emirlerin sayısı da tartışılan konular arasındadır. Utbî, Gerdîzî ve Beyhakî'nin topluca bir arada ziketmediği hanedan emirleri, modern araştırmacılar tarafından farklı sıralamalarla bazen şahıslar ve kişiler karıştırılarak anlatılmıştır. Müsteşrik Zambour, ailenin başlangıç tarihi olan 279/892'den 401/1010'a kadar dört emirin hanedanın başına geçtiğini dile getimiştir. Bunların ise 279/892 yılında Ahmed b. Ferîgûn'un, 337/948 yılında Ebü'l-Hâris Muhammed b. Ferîgûn'un (ö.390/999), 368/978 yılında Ebü'l-Hâris Ahmed b. Muhammed'in (ö.401/1010) olduğunu nakletmiştir (Zambour, 1980, s. 311). Leyla Şah, 1. Ferîgûn, 2. Ahmed b. Ferîgûn'un, 3. Ebü'l-Hâris Muhammed (Ahmed) b. Ferîgûn'un, 4. Ferîgûn b. Muhammed'in, 5. Ebû Nasr Ahmed-i Ferîgûnî ve 6. olarak Hasan Ferîgûnî'nin hanedanın başına geçtiğini dile getirmiştir. Bu sıralamada Ebü'l-Hâris Muhammed ile Ebü'l-Hâris Ahmed aynı kişi olarak değerlendirilmiştir (Hüseynî, 2020, s. 76).

Afgan tarihçi Abdülhay Habîbî ise 250/864 yılında Ferîgûn, 279-340/892-951 yıllarında Ahmed b. Ferîgûn'un, 340-389/951-998 yılları arasında Ebü'1-Hâris Muhammed b. Ahmed'in, 394/1003 yılında Ferîgûn b. Muhammed'in, 394-401/10031010 yıllarında Ebû Nasr Ahmed b. Muhammed'in ve 401/1010 yılında Hasan b. Ebû 
Nasr Ahmed'in hanedanın başında olduğunu zikretmiştir (Habîbî, 2011, s. 8). Bizim kanaatimize göre Ferîgûnî emirlerin bazıları isim benzerliğinden dolayı aynı kişiler sanki farklı kişiler olarak algılanmıştır. Bunların ilki dönemleri ve faaliyetleri aynı olup farklı kişiler olarak zikredilen Ebü'l-Hâris Muhammed ile Ebü'l-Hâris Ahmed'dir. İkincisi de Ebü'l-Hâris Muhammed'in ardından zikredilen hanedan içinde öne çıkmış Ferîgûn b. Muhammed'dir. Hâlbuki Utbî'nin açık bir şekilde zikrettiğine göre Ebü'lHâris'ten sonra Ebû Nasr Ahmed hanedanın başına geçmiştir. Buna göre Ferîgûnîlerin hanedanında yedi emir iş başına gelmiştir. Bunlar ise Ferîgûn (250/864), Ahmed b. Ferîgûn (279-340/892-951), Ebü'1-Hâris Muhammed b. Ahmed b. Ferîgûn (340-389/951998), Ebü'l-Hâris Ahmed b. Muhammed (394-1003), Ferîgûn b. Muhammed (394/1003), Ebû Nasr Ahmed b. Ebü'l-Hâris Muhammed b. Ferîgûn (401/1010) ve Hasan b. Ebû Nasr Ahmed (401-407/1010-1019)' dir.

Hanedanın merkezi ise günümüzde Kuzey Afganistan topraklarında bulunan Cüzcân'dır. Kadim bir ilim ve kültür şehri olan Cüzcân, gerek İslamiyet öncesi ve gerekse İslamiyet sonrası hep Türk yurdu olmuştur. Ancak muasır İran araştırmacıları eski Fars milliyetçiliğinin de etkisiyle ilmi ve akademik anlayıştan saparak bilimsellikten uzak yayılmacı ve taraflı bir perspektiften konuyu ele alarak nerdeyse tüm Türkistan şehirlerini İran bölgesi, hanedanlarını ise Fars asıllı göstermeye çabalamışlardır. İranlı araştırmacılar gibi Yazıcı da Ferîgûnîler'i İranlı bir hanedan olarak göstermiştir (Yazıcı, 1994, s. 398). Dönemin tarihçileri olan Utbî, Gerdîzî ve Beyhakî’nin asla dile getirmediği, Mâverâünnehir, Türkistan ve Horasan olarak naklettikleri bölgeleri, günümüz araştırmacıları İran coğrafyası olarak telakki etmişlerdir. Hâlbuki ünlü coğrafyacı İbn Havkal, Horasan'ın kapsadığı bölgelerden bahsederken Cüzcân dâhil kuzey Horasan'dan Türk yurdu, güney Horasan'dan ise Fars ve Kûmis olarak bahsetmektedir (İbn Havkal, 1938, s. 426; Gerdîzî, 1985, s. 361; Utbî, 1966, s. 294). Nitekim Hudûdü'l-Âlem bölgenin Türk yurdu olduğunu vurgulamakta ve Horasan'dan "Türk yurdunun kapıları olarak" söz etmektedir (Hudûdü'l-Âlem, 1999, s. 73). Söz konusu İranlı araştırmacıların bölgede güçlü ve muktedir devletler olarak varlığını kanıtlayan Sünni İslam politikaları takip eden Karahanlılar, Gazneliler, Selçuklular ve Timurlular gibi Müslüman devletler hakkında da aynı yargıyı vermedikleri görülmektedir. İran'ın dil ve kültür varlığını yaşatan mezkûr devletleri sadece dini ve mezhep politikalarından dolayı yağmacı ve göçebe olarak aktarmaktadırlar. Buna binaen dönemin tarihçilerinden Abdülcebbâr Utbî, Gerdîzî ve Beyhakî ile modern çalışmalara kıyaslama yapılarak Ferîgûnîler hakkındaki bilgileri aslına uygun objektif bir şekilde yorumlamak mümkündür.

\section{Ferîgûn (250-279/864-892)}

Ferîgûnîlerin atası olarak bilinen Ferîgûn, 3/9. yüzyılın sonuna doğru hanedanın başında bulunan ilk hanedan üyesi ve kurucusudur. Dönemin kaynakları ile modern araştırmalarda onun hakkında fazla bilgi bulunmamaktadır. Onun hakkında aktarılan yegâne net bilgi 3/9. yüzyılda günümüz Fâryâb ili ile Cüzcân arasında yaptırmış olduğu Ribat-1 Ferîgûn'dur (İbn Havkal, 1938, s. 444; (Hudûdü'l-Âlem, 1999, s. 76). Boswroth söz konusu ribatın Cüzcân'ın kuzeyinde günümüzde Fâryâb'ın ilçelerinden olan Andhûy'un yakınlarında olduğuna işaret eder (Bosworth, 1984, s. 755). 


\section{Ahmed b. Ferîgûn (279-340/892-951)}

Dönemin temel kaynakları hanedanın atası Emir Ferîgûn'dan ziyade oğlu Ahmed b. Ferîgûn'dan söz etmekte, onun 279/892 yılında hanedanın başında olduğunu aktarmaktadır (Utbî, 1966, 343; Zambour, 1980, s. 311). Sâmânî Hükümdarı İsmail b. Ahmed, Mâverâünnehir bölgesinde hâkimiyet sağlayınca Abbâsî Halifesi Mutezıd tarafından tanındı. Bunun üzerine merkezleri Sîstan olup Horasan hâkimiyeti hayallerini kuran Saffârî Emiri Amr b. Leys, Belh Emiri Ebû Dâvud, Cüzcân Emiri Ahmed b. Ferîgûn ve Mâverâünnehir Emiri İsmail b. Ahmed'e mektup göndererek kendisine itaat etmelerini talep etti. Bunun üzerine Belh Emiri Ebû Dâvud ile Cüzcân Emiri Ahmed b. Ferîgûn olumlu cevap vererek itaatlerini bildirdiler. Fakat Sâmânî Hükümdarı İsmail, ona karşı çıkarak savaş hazırlığı yaptı. Rabîülevvel 287/Mart 900 tarihinde Mâverâünnehir civarında aralarında çıkan savaşta Saffârî Emiri Amr b. Leys, yenilgiye uğradı, esir düştü (Târîh-i Sîstân, 2011, s. 257). Böylece Cüzcân dâhil, Horasan'ın kuzey kısmı Sâmânîlerin hâkimiyeti altına girdi. Bu gelişmeden sonra Ferîgûnî hanedanını da Saffârîlerlerden sonra Sâmânîlere bağlı bir yönetim haline geldi (Hüseynî, 2020, s. 12) Muasır Afgan tarihçilerinden Gubar, Ferîgûnîlerin 283/897 yılında Sâmânîlerin himayesine girdiğini nakletmektedir (Gubar, 2005, s. 105).

Bir zamanlar Ferîgûnîleri tahakküm altına alan Saffârîlerlerin Emiri Halef b. Ahmed tarihin bir cilvesi olsa gerek bir müddet sonra Gazneli Mahmud döneminde Ferîgûnîlerin diyarına sürgün olarak gönderildi. Naklediğine göre Gazneli Mahmud Saffârîlerlerin merkezi Sistân'ı zapt ettikten sonra hükümdarlarına defalarca eman vermesine rağmen isyanlarını devam ettirdiler. Bunun üzerine Gazneli Mahmud, ulemanın reyi dâhilinde huzur ve istikrarın kalıcı olması adına Halef b. Ahmed'i Âl-i Ferîgûn'un diyarı Cüzcân'a gönderdi. Ahmed b. Halef'in hileci bir kişiliğe sahip olduğunu bildiği için onu Cüzcân'a göndererek müttefikleri sayesinde Sistân'ı kontrolü altına aldı. Emirliğinin nasıl sonladığ hakkında fazla bilgi olmayan Ahmed b. Ferîgûn'un zengin bir emir olduğu, bir nevruz gecesinde at ahırlarında bir gecede atlarının bin baş tay doğurduğu nakledilmektedir (Munis, 1987, s. 232). Bu zenginliğine yanı sıra çok cömert olduğu, edip ve şairleri ikram ve bahşişlerle çokça sevindirdiğide zikredilmektedir.

\section{Ebü'l-Hâris Muhammed b. Ahmed b. Ferîgûn (340-389/951-998)}

4/10. yüzyılın sonlarında Ferîgûnîlerin başında bulunan üçüncü emir Ebü'l-Hâris Muhammed b. Ahmed b. Ferîgûn'dur (Gubar, 2006, s. 105; Habîbî, 2011, 6; Yazıc1, 1995, s. 388 ). Saffârîler'den Amr b. Leys'e (879-902) tâbi olan Ahmed b. Ferîgûn'dan sonra yerine oğlu Ebü'l-Hâris Muhammed geçerek Sâmânîlerle ailevi ilişkiler kurmuştur (Gerdîzî, 1985, s. 361). Beyhakî'nin naklettiğine göre Ebü'l-Hâris Muhammed, Ramazan 384/Ekim 994 tarihinde Sebük Tegin'in yanında Nîşâbur'a saldıran isyancı emirler Ebü'l-Hasan Simcûrî ve Fâik el-Hassa'ya karşı savaşa katılmış, isyancı emirler yenilgiye uğratılmıştır (Beyhakî, 1998, s. 312; Utbî, 1966, 118). Ebü'l-Hâris Muhammed, 340-389/951-998 yılları arasında Ferîgûnî hanedanını iyi ve huzurlu bir şekilde idare etmiş, bu süreçte ilim ve irfana değer vermiştir. Bundan dolayı 372/982 yılında anonim Hudûdü'l-Âlem mine'l-Maşrik-i ile'l-Mağrib adlı eser kendisine ithaf edilmiştir (Gubar, 2006, s. 105; Habîbî, 2011, 6; Yazıcı, 1995, s. 388). 


\section{Ebü'1-Hâris Ahmed b. Muhammed (389-394/998-1003)}

Ferîgûnîlerin dördüncü emiri olan Ebü'l-Hâris Ahmed b. Muhammed, Utbî ve Gedîzî'nin naklettiklerine göre Ebü'l-Hâris Ahmed, hem Sâmânîler ve hem de Gaznelilerle ailevi ilişkiler kurmuştur (Utbî, 1966, s. 118; Gerdîzî, 1985, s. 361). Sâmânîler zayıflayınca Gaznelilerle ilişkilerini pekiştirerek Gaznelilerin daveti üzerine savaşlara katılmıştır (Utbî, 1966, s. 118). Sebük Tegin'in kızlarından birini oğlu Ebû Nasr ile kendi kızlarından birini de Gazneli Mahmud ile evlendirerek ilişkilerini daha da güçlendirmiştir (Fazlullah, 2008, 15; Gubar, 2005, s. 105; İbn Haldun, 2000, s. 484). Böylece Gazneliler'le Ferîgûnîler arasındaki dostluk ve iş birliği daha da güçlenmiştir.

Ebü'l-Hâris Ahmed, Sebük Tegin vefat edince İsmail'e karşı Gazneli Mahmud'u destekleyerek kız kardeşiyle evlenmiştir (Gubar, 2005, s. 105). Bir müddet sonra da İsmâil ile Mahmud arasındaki anlaşmazlıkların giderilmesinde aracılık etmiştir (Utbî, 1966, 294). Gazneli Mahmud, kardeşi İsmâil'i yenip tahtı ele geçirdiği vakit kardeşini Ebü'1-Hâris'in gözetiminde bırakmıştır (Yazıc1, 1995, s. 389).

Bu durumu siyasî evlilik olarak nitelendirenler olsa da uygulamada samimi bir şekilde Gaznelilere bağlı oldukları, Sultan Mahmud'un da Ebü'l-Hâris Ahmed'e çok güvenip itimat ettiği görülmüştür (Hüseynî, 2020, s. 12). Ebü'l-Hâris Ahmed de Gaznelilerin Hindistan seferleriyle Karahanlı ve Sâmânîlere karşı yapılan seferlere katılarak samimiyet ve bağlılığını kanıtlamışlardır.

Bu sırada Sâmânî ordu emirlerinden Fâik el-Hassa, Sâmânî emiri Nuh b. Mansur'a karşı isyan ederek Belh ve Tirmiz taraflarına sığınmıştır. Nuh b. Mansur'a karşı savaşmak üzere ordu toplamaya çalışmıştır. Bunun üzerine Sâmânî Emiri, Ebü'lHâris'in isyancı emire karşı savaşmasını istemiştir. Fakat Ebü'l-Hâris, Fâik el-Hassa'ya karşı yenilgiye uğramıştır (Utbî, 1966, s. 93). Belh'e hâkim olan Fâik el-Hassa, Sâmânîlere karşı isyan eden diğer isyancı Simcûrîlerin lideri Ebû Ali Simcûrî ile ittifak kurmuştur. Bu gelişmeyi büyük tehdit olarak gören Sâmânî Hükümdarı Nuh b. Mansur, savaş hazırlığı yapıp büyük bir ordu hazırlayarak Cüzcân'a girmiştir. Ebü'lHâris Ahmed ve Garcistân Emiri Şâr gibi bazı Horasan emirleri de ona katılmıştır. Ramazan 384/Ekim 994 tarihi Salı günü meydana gelen savaşta isyancı Ebû Ali Simcûrî ve Fâik el-Hâssa yenilerek firar etmiştir (Utbî, 1966, s. 104).

\section{Ferîgûn b. Muhammed (394/1003)}

Ebü'l-Hâris Muhammed'in vefatından sonra kimin yönetimin başına geçtiği ihtilaflı bir konudur. Bu sebeple kimi tarihçiler Ferîgûn'u Ferîgûnî emirler arasında saymamışlardır. Fakat Utbî'nin de işaret ettiği gibi Ferîgûn b. Muhammed'in Ebü'lHâris Ahmed'den sonara yönetimin başına geçtiğini kuvvetle muhtemeldir. Nitekim Utbî, Ferîgûn b. Muhammed'in 394/998 y1lında Gazneli Mahmud'un daveti üzerine kırk sancaklı emirle son Sâmânî temsilcisi İsmail b. Nuh'a (Muntasır) karşı savaşmaya gittiğini dile getirmiştir (Utbî, 1966, s. 197). Nitekim Hâbîbî ve Leyla Şah gibi muasır araştırmacılar Ebü'l-Hâris Muhammed'den sonra oğlu Ferîgûn b. Muhammed'in hanedanın başına geçtiğini öne sürmüşlerdir (Habîbî, 2011, 6; Hüeynî, 2020, s. 90).

6. Ebû Nasr Ahmed b. Ebü'1-Hâris Ahmed b. Muhammed (394-401/1003-1010)

Ferîgûn b. Muhammed'dun kısa yönetiminden sonra kardeşi Gazneli Mahmud'un emriyle hanedanın başına geçmiştir (İbn Haldun, 2000, s. 485). İbn'ül-Esir, 389/999 yılı 
olayları hakkında bilgi verirken Gazneli Mahmud ile Ferîgûnîlerin ilişkilerine değinmiş fakat o dönemde Ferîgûnîlerin başında bulunan emirden söz etmemiştir (İbnü'l-Esîr, 1987, s. 66). Bosworth, Ebû Nasr Ahmed'den önce 394/1003 yılında Ferîgûnîlerin başında Ferîgûn b. Muhammed adlı bir emirin Gazneli Mahmud'a bağlı olarak hüküm sürmüş olabileceğini dile getirmiştir. Utbî'nin açık bir şekilde Ebü'lHâris Ahmed'den sonra oğlu Ebû Nasr Ahmed'in geçtiğini kesin bir şekilde dile getirmesi Boswroth'un bu görüşünü çürütmektedir (Utbî, 1966, s. 295).

Utbî'nin aktardığına göre babasının vefatından kısa bir süre sonra Horasan bölgesini hâkimiyeti altına alan Gazneli Mahmud, bir müddet sonra Belh'in batısında bulunup Ferîgûnî hanedanı tarafından yönetilmekte olan Cüzcân bölgesini topraklarına katmıştır (Utbî, 1966, s. 295). Hanedan fertlerinden Ebû Nasr Ferîgûnî'yi Cüzcân valisi olarak tayin etmiştir (Utbî, 1966, s. 280; İbnü'l-Esîr, 2004, s. 5417; Bayur, 1987, 138). Gazneli Mahmud'un kendisine çok güvendiği, akıllı ve becerikli bir devlet adamı olarak gördügü Ebû Nasr Ferîgûnî de hep Gazneli Mahmud'a karşı sadık kalmıştır. 397/1007 yılında Gazneli Mahmud'un Mültan seferiyle meşgul olduğunu fırsat bilerek Horasan'a saldıran İlik Han Nasr'a karşı duran ordunun içinde yer almıştır. Gazneli Mahmud'un kardeşi Emirü'l-Ceyş Nasr, Arap kökenli askerlerin emiri Ebû Abdullah et-Tâî, Herat valisi Emir Hâcib Altuntaş ve Tûs valisi Arslan Câzib ile beraber sağlam bir duruş sergileyerek Gazneli topraklarını Karahanlılara karşı savunmuştur (Utbî, 1966, 286, 295; Zeki, 2019, 203).

Utbî'ye göre Ebû Nasr Ahmed, Gazneli Mahmud'un kendisine güvendiği Ferîgûnî emirlerindendir. Nitekim o, 399/1008 yılında Hindistan'a düzenlenen Bhim Nagar seferine katılmış, kızını Sultan Mahmud'un oğlu Muhammed ile evlendirmiştir (Gubar, 2005, s. 106). Ayrıca Gazneli Mahmud, Karahanlı hükümdarı İlik Nasr (İlik Han)'a karşı savaşırken Ebû Nasr Ahmed'i, merkez kuvvetlerinin başına getirmiş, Yanında kardeşi Nasr b. Sebük Tegin'i bulundurduğu ordu söz konusu savaşta İlik Han Nasr yenilgiye uğratmıştır (Utbî, 1966, s. 295).

İbnü'l-Esîr'e göre bu savaştan sonra Gazneli Mahmud'un kız kardeşiyle evli olması sebebiyle akrabası olan Cüzcân Emiri Ebû Nasr Ahmed, 401/1010 yılında vefat etmiştir. Yine İbnü'l-Esîr'in naklettiğine göre Ebû Nasr Ahmed ve babası ulemayı seven ve onlara iyilik gösteren emir olarak tarihe geçmişlerdir (İbnü'l-Esîr, 1987, s. 66). Gazneli Mahmud'un aynı zamanda eniştesi olan Ebû Nasr, 401/1010 yılında vefat edince (Utbî, 1966, 295) yerine Gazneli Mahmud'un oğlu ve Ebû Nasr'ın da damadı olan Ebû Ahmed Muhammed tayin edilmiştir. Ebü'l-Hasan Muhammed b. Mehran'1 veziri tayin eden Ebû Ahmed Muhammed Cüzcân valisi olarak göreve başlayınca adaletli davranışlarıyla halkın gönlünü kazanmış, Cüzcân halkı da ona sadık kalarak hizmet etmeye devam etmiştir (Utbî, 1966, s. 369).

\section{Hasan b. Ebû Nasr Ahmed (401-407/1010-1016)}

Utbî'nin aktardığına göre Ebû Nasr vefatının sonra Gazneli Mahmud, 401/1010 yılında kendi oğlu Ebû Ahmed Muhammed'i Cüzcân valisi olarak tayin etmiştir (Utbî, 1966, s. 369). Fakat dönemin tarihçisi Beyhakî, 401/1010 yılı hadiselerini anlatırken Ferîgûnîlerin başında Gazneli şehzadeleri Muhammed ve Mesud'un hem sohbeti olan Hasan adlı bir kişinin olduğunu kaleme almıştır (Beyhakî, 1998, s. 176). Beyhakî’nin 
Hasan b. Ferîgûn olarak naklettiği bu kişinin de Ebû Nasr b. Ahmed'in oğlu olması kuvvetle muhtemeldir. Gazneli Mahmud, 401/1010 yılında Gûr savaşına gittiğinde oğulları Mesud ve Muhammed'i Cüzcân'da Hasan'ın yanında bırakmıştır. Aynı yıl içinde Hasan, Cüzcan'da hanedanın başına geçmiştir. Fakat Hasan'ın emirliği fazla hüküm sürmemiş, Gazneli Mahmud, Ferîgûnî hanedanına son vererek bölgeyi doğrudan hâkimiyet sahasına dâhil etmiştir (Yazıc1, 1995, s. 399). Böylece Ferîgûnîler hanedanı, 408/1017 yılında tamamen ortadan kalkmış, bölge Gaznelilere bağlanmıştır (Vehbî, 1884, s. 101).

\section{FERÎGÛNÎLERDE İKTISSADİ, ILLMÎ VE KÜLTÜREL HAYAT}

Cüzcân, Ferîgûnîler döneminde mamur ve müreffeh bir şehirdi. Dönemin coğrafi kaynaklarında bağrında altın, gümüş, demir ve sürme taşları gibi madenleri barındıran bir belde olarak tasvir edilen Cüzcân, aynı zaman ticaret ve sanatın merkezi olarak da zikredilir (İbn Havkal, 1938, 443). Tarım ve ziraat açısından gelişmiş bir bölge olarak anlatılan Cüzcân'ın özellikle Şubûrkân (Şibirgân) nahiyesi meyveleriyle meşhurdur. Cüzcân'da üretilen deri ve deri ürünleri Horasan ve Mâverâünnehir'e ihraç edilir, beyliğin iktisadi hayatına önemli katkıda bulunurdu. Belh ve Fâryâb'a olan ticaret yolları, tarım ürünlerinin yanı sıra kumaş ve dokuma pazarını canlandırmıştı. Cüzcân iktisadi hayatının can damarı olan ticaretin yanı sıra kıymetli madenler, ziraat ve deri sanayinin de etkisiyle zenginleşmiş, Ferîgûnîlerin ilim ve irfanını desteklemeleriyle her açıdan mamur ve müreffeh bölge olmuştu (İbn Havkal, 1938, s. 443; Hüseynî, 2020, s. 12).

Ferîgûnîler, siyasî açıdan başarılı oldukları gibi ilim, kültürel ve edebiyat açısından da dönemin üst seviyelerine ulaşmışlardır. Bu konuda da şüphesiz temel referansımız Utbî’dir. Onun naklettiğine göre Ferîgûnî emirleri, dirayetli kişiler olup âlim, ârif ve edipleri etraflarına toplayarak izzet ve ikramda bulunmuşlardır. Bu doğrultuda bölgenin ilmî seviyesini zirveye ulaştırmış, dünyanın ünlü ediplerini saraylarında ağırlamışlardır. Onların sarayında yetişip şan ve şöhretlerini mektup ve şiirlerinde yansıtan dönemin ünlü ediplerinden biri de Sebük Tegin'in veziri Ebü'l-Feth Büstî'dir. Büstî şiirlerinde Ferîgûnî emirlerin ulemaya karşı ilgi ve saygısını dile getirmiş, kedisine yapılan ihsanlarından övgüyle bahsetmiştir. O, bir şiirinde Ferîgûnî ailesini şöyle tasvir etmiştir:

$$
\begin{aligned}
& \text { ألم تر أنِّي في نهضتبلقيت الغنى و المنى و الأميرا }
\end{aligned}
$$

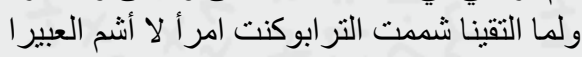

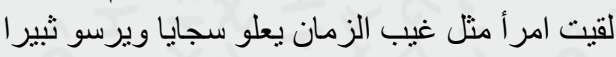

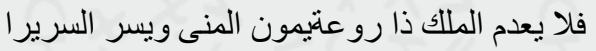

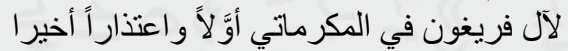

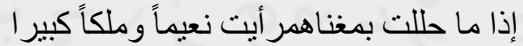

“Görmedin mi ben yolculuğumda arzularıma ulaştım, emiri gördüm. Emir bana baktığı zaman toprak koklamaya başladım, toprağa düşerek bayıldım. Hâlbuki beni amber kokusunu koklamayan biriydim. Öyle bir emir gördüm ki insanların en çok görmek istediği tabloydu. O emir yüksek bulut ve Mekke'nin Sebir dağ1 gibidir. Ferîgûnî Emirleri iyilikte önde olumsuz konularda ise geridedirler. İnanılmaz ve halkı arzularına kavuşturdukları için devlet ve mülkü elden vermezler. Tahtlarını sevindirirler. Onların saraylarına girdiğim zaman nimetler ve büyüklüğe şahit olurum 
diyerek" Ferîgûnîlerin üstün vasıflarını iltifatlarıyla dile getirmiş, hanedanının yüceliği ve büyüklügünü zikretmiştir (Utbî, 1966, s. 297). Şiirlerinde sıkça Ferîgûnî emirlerin cömertliğinden bahseden Ebü'l-Feth Büstî şöyle devam eder:

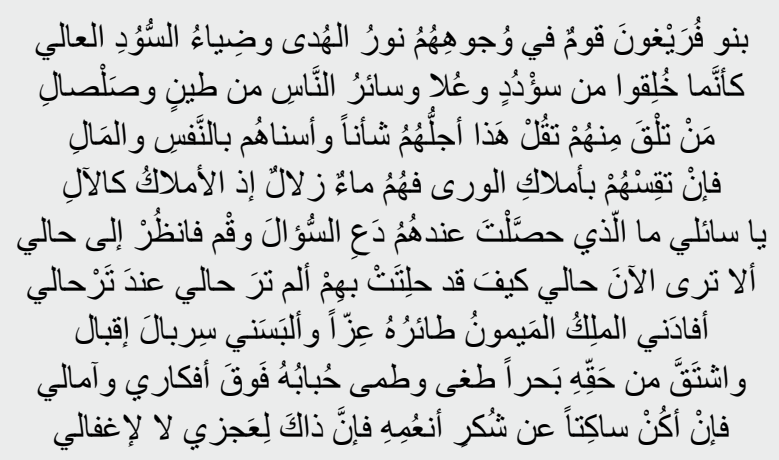

“Ferîgûnîler simalarında hidayet ve rıf'at (yücelik) olan bir topluluktur. Sanki onlar ulu ve efendilik için yaratılmış, diğer sair insanlar çamur ve balçıktan yaratılmışlardır. Onlardan kimi görürsen dersen ki bu onların içinde en cömert insandır. Ey sorgulayıcı! Bana onlardan ne elde ettiğimi sorarsan? Benim halime bak! Görmüyor musun? Halim onların vesilesiyle nasıl süslenmiş ve bezenmiş? Benim bu halimi görmemiş miydin? Onların nimetlerine karşı sessiz kalırsam kasıtlı olarak değil benim acizliğimdendir" diyerek Ferîgûnîlerin yüceliğinden izzet ve ikramından ve Ebü'l-Feth Büstî kendisinin yetişmesindeki rollerinden de bahsederek, onların ilme ve âlime karşı gösterdiği ilgi ve saygiyı dile getirmiştir (Utbî, 1966, s. 298).

Ebü'l-Hâris'in teşvik ve desteğiyle Hudûdüll-Âlem mine'l-Meşrik ile'l-Mağrib adlı meşhur eser Farsça olarak kaleme alınmış, dönemin ünlü âlim, arif ve ediplerinden olan Ebü'l-Fazl Ahmed b. Hüseyin, Bedîuzzaman el-Hemedânî gibi zatlar Ferîgûnîlerin sarayında yerleşerek bazı emirlerin kâtipliklerini ve danışmanlıklarını yapmıştır. Dönemin ediplerinden ve siyaset bilimcilerinden Sebük Tekin'in divân-1 resâil kâtibi olan Ebü'l-Feth Büstî, Ferîgûnîlerin emirlerini övdüğü şiirlerinde o, emirlerin ulemaya karşı ne kadar cömert olduğunu anlatarak Ferîgûnîlerin âlimlere ve fazıllara yönelik inam ve ikramlarını sürdürdüklerini zikreder (Utbî, 1966, s. 294; Hüseynî, 2020, s. 13).

İbnü'l-Esîr de hanedanın ilim ve irfana verdiği değere işaret etmektedir (İbnü'lEsîr, 1987, s. 66). Cafer b. Sehl b. Merzbân gibi birçok âlim ve edip Ebü'l-Hâris'in kâtip ve danışmanlığını yapmıştır. Cafer, ayrıca mektuplar yazarak muhtaçların yardımına koşmuş ve teselli etmiştir. Han ve kervansaraylar yaparak yolda kalmışlara sahip çıkmıştır (Yazıcı, 1995, s. 388; Hüseynî, 2020, s. 12). Ayrıca Ebû Süleyman el-Cûzcânî (ö. 200/816), Ebû İshak el-Cûzcânî (ö. 259/873), Ebû Bekir el-Cûzcânî (ö. III./IX. Yüzyıl) , Ebû Ali el-Cûzcânî (ö. III/IX Yüzyıl) ve Minhâc-1 Sirâc el-Cûzcânî (ö. 664/1266'dan sonra) gibi âlimler Ferîgûnîlerin Cüzcân'da oluşturdukları ilmi ve kültürel muhitte yetişen meşhur âlimler arasında yer almaktadır (Yazıcı, 1994, s. 97). 


\section{SONUÇ}

892-1010 yılları arasında Cüzcân merkezli bir hanedan kuran Fêrîgûnîler bazen bağımsız bazen de sırasıyla Saffârîlerler, Sâmânîler ve Gaznelilere bağlı emirler olarak varlıklarını Horasan'da 120 yıl kadar sürdürmüşlerdir. Ferîgûnîlerin, alışılmış ve nakledilmiş bilgilerin aksine temel kaynaklar doğrultusunda Ehl-i Sünnet çizgisine mensup, Türk yurdu Cüzcân'da hâkimiyet kuran bir Türk Beyliği oldukları görülmüştür. Gerek fetih öncesi ve gerek fetih sonrası Cüzcân bölgesinin bir İran toprağı olmadığı, Ferîngûnîlerin İran'a mensup bir aile olmadıkları dönemin temel kaynakları çerçevesinde aydınlatılmıştır. Ferîgûn'un İran krallarından Ferîdûn'la hiçbir ilgisi olmadığı, bu konudaki yorumların bilgiden yoksun, zorlama yorumlarla kaleme alındığı, temel kaynaklardaki bilgilerin objektif değerlendirilmediği anlaşılmaktadır.

Her ne kadar Ferîgûnîlerin kökleri isim benzerliğinden dolayı İran kralı Feridun'a intisap ettirilerek tartışılsa da memleketleri Türkistan, dinleri İslam, mezhepleri Hanefî Ehl-i Sünnettir. Ferîgûnî hanedanın başına kimlerin geçtiği çalışmanın temel sorunlarından biri olarak karşımıza çıkmıştır. Hanedan kurucusu Ferîgûn ve oğlu Ahmed'den sonra kimin veya kimlerin hangi tarihte hanedanın başına geçtikleri ihtilaflı olup bilgi yetersizliğinden dolayı net olarak ortaya konulamamıştır. Utbî gibi temel kaynaklar isimleri özet geçerken bazı modern kaynaklar da Ahmed $b$. Ferîgûn'dan sonra gelenleri karıştırmış, kimileri Ebü'l-Hâris Muhammed'le Ebü'lHâris Ahmed'i farklı kişiler olarak göstermişlerdir. Bu çalışmada ise hanedan mensuplarının civar devletlerle ilişkiler, özellikle Gaznelilerle olan ailevi ilişkileri ve tarihleri dikkate alınarak Ebü'l-Hâris Muhammed'le Ebü'l-Hâris Ahmed'in aynı kişi oldukları belirtilmiştir.

Adını kurucuları Ferîgûn'dan alan Ferîgûnîlerın başına geçen emirler barış yanlısı, ilmi ve ulemayı destekleyen ve koruyan bir hanedan olarak karşımıza çıkmaktadır. Hanedan mensuplarının ulema ile istişare ederek edip ve şairlerle hem sohbet oldukları, adalet ve hüsnü muameleleriyle şöhret kazandıkları görülmektedir. Bundan dolayı dönemin şair ve edipleri Seâlebî, Bediuzzaman el-Hemedanî, Ebü'l-Feth Büstî, Ebû Bekir Muhammed b. Abbas Hârizmî, Ebû Nasr Abdülcebbar Utbî Ferîgûnîlerden övgüyle bahsetmektedirler. Gaznelilerle ailevi ilişkiler kurarak bir müddet mevcudiyetlerini koruyan Ferîgûnîler, 410/1010 yılında Gazneli Mahmud'un oğlu Muhammed'i Cüzcân valisi olarak göndermesiyle siyasi olarak tarih sahnesinden çekilmişlerdir. Fâryâb, Anbâr ve Talikan bölgelerini içine alan Cüzcân da tamamen Gaznelilerin hâkimiyeti alanına girmiştir.

\section{EXTENDED SUMMARY}

The Ferîgûnîs, known as Âl-e Farîghûn, is a semi-independent Khorasan principality that ruled in Juzjan, which included the regions of Ambâr, Shirbirghân and Fâryâb between 279/892 and 401/1010. Their rulers were subordinated to the Saffârîd, Sâmânîd and Ghaznavids, respectively. Establishing family relations with the Ghaznavids mostly, the Farîghûnids dynasty was terminated by Mahmud of Ghaznavids and its lands were annexed to the Ghaznavid lands. It is evident in historical sources that the concept of Farîghûn is used for a large geography extending to Kharizm and Mavaraunnahir, including today's northern Afghanistan, and that 
these regions are the south of Turkistan, where Turks live intensely. Nevertheless, some contemporary Iranian researchers such as Layla Shah Husayni tried to attribute the origins of the Farîgunîd to Iran and to the former Iranian king Farîdûn by making forced comments. They based this on the sentence "Avlâd-1 Afarîdûn" in the work named Hudûdu'l-Alam Mine'l-Mashriq Ile'l-Maghrib. However, "Avlâd-1 Afrîdûn" or "Avlâd-1 Farîghûn" mentioned in the work and other works are the Juzcân Orders. As a matter of fact, Ibn Khaldun and the Ottoman historian Aga Pasha also referred to the Juzcân Emir as "Bani Farîghûn". Therefore, the claims that the Farîghûnids are descendants of Feridun based on the aforementioned sentence show that they are baseless and inconsistent.

Farîghûnids is a semi-independent Turkish dynasty that ruled in Juzjan located in the north of today's Afghanistan, between 278-401 and 892-1010. They established political and familial relations with the Sâmânîd and Ghaznavids, and also managed to maintain their presence in the region for a long time thanks to their peaceful and intelligent behavior. The borders of the Farighunids extended from the north to Âmu Darya, from the south to Gharjistan, Ghur and Talikan. Ghur Shah, who ruled in Ghur, was subordinate to the Ali-i Farighon. The only known information about the family of Farighun's is that the dynasty that lived around Ribat of Farîghûn in the third century of reported by al-Utbî. In the sources of the period, six people are mentioned as the orders of the family. At the beginning of the dynasty, Farighûn was the founder of the dynasty in 278/892, but there is not much information about him.

After Farîghûn's death, his son Ahmad ruled the dynasty between 279-340 / 892951. He was sent by Seffarid Amir Amr b. Lays as governor to Belh to set up a barrier against the Sâmânî Amir İsmail. The third Emir of the dynasty was Ebü'l-Hâris Muhammed b. Ahmed. An anonymous work titled Hudûdu'l-Alam mine'l-Mashrik-i ile'l-Maghrib was presented to Abu'l-Hâret, who is an emir who favored science and scholars, in 372/982. After Abu'l-Hâret Muhammed, who had good relations with the Ghaznavids, for a short time in 394/1000, his son Ferîghûn b. Mohammad had got throned. After the period of Ferîghûn, which did not last long, his brother Abu Nasr Mohammad b. Abu'l-Hâret Muhammed b. Ahmed b. Ferîgûn maintained family and friendly relations with the Ghaznavids. The last emir of the Farîghûnîds, Hasan b. Abu Nasr Ahmad between the years 892-1010, the Farîghûnîd, who preserved and defended their Juzjan-centered semi-independent existence, established friendly and family relations by adhering to the Saffârîlers, Sâmânîs and Ghaznavids respectively. In this study, it was concluded that the Farîghûnîd were a Turkish principality that was a member of the Ahl-i Sunnah line and ruled over the Turkish homeland Juzcân, in line with the basic sources, in contrast to the usual and reported. It has been enlightened within the framework of the basic sources of the period that the Juzjan region before and after the conquest was not an Iranian land and that the Pharisees were not a family of Iran. It has been detected that Ferîgûn has nothing to do with Ferîdûn, one of the Iranian kings, and that his comments on this subject were written without knowledge, with forced comments, and that his knowledge in basic sources was interpreted outside the purpose. Although their roots are discussed by being 
affiliated with the Iranian king Faridun due to the name resemblance, their homeland is Turkestan, their religion is Islam, and their sect is Hanafi Ehl-i Sunnah.

The rulers of the Farîghûnids, who are named after their founder Farîghûn, appear as a dynasty that loves peace and science. It is seen that the members of the dynasty, in consultation with the ulama and chatting with the poets, gained fame with their treatment of justice and goodwill. Therefore, the poets and bottoms of the period, Poet Seâlebî, Badiuzzaman al-Hamadanî, Abu'l-Fath Bustî, Abu Bakr Muhammad b. Abbas Khârizmî speaks highly of Abu Nasr Abduljabbar Utbî Ferîghûnîd. The Farîghûnids, who maintained their existence for a while by establishing family relations with the Ghaznavids, politically withdrew from the stage of history in 410/1010, when Mahmud Ghaznavids son Muhammad was sent as the governor of Juzjan. Although their roots are discussed by being affiliated with the Iranian king Faridun due to the name resemblance, their homeland is Turkestan, their religion is Islam, and their sect is Hanafi Ahl-i Sunnah. 


\section{KAYNAKÇA}

Ağa Paşa, H. İ. (1909). Vakâyî̀- târîhiye. İstanbul: Matbaa-1 Kütüphane-i Cihan.

Âmini, M. K. (2009). Coğrafyayı-ı umumi-i Fâryâb. Kâbil: Matbaa-ı Meslek-i Afgan.

Anonim. (1983). Hudûdü'l-Âlem mine'l-Maşrik ile'l-Mağrib. (Minûçehir, S., Çev.). Tahran: Kitâbhâne-i Tahurî.

Anonim. (1999). Hudûdü'l-Âlem mine'l-Maşrik-i ile'l-Mağrib. (Yusuf H.. thk.). Kahire: ed-Dâr Li'sSekafet-i Li'n-Neşir.

Anonim. (2011). Târîh-i Sîstân. (Bahar. M. thk). Tahran: Asâtir.

Bayur, H. (1987). Hindistan tarihi, I. Ankara: Türk Tarih Kurumu Yayınları.

Beyhakî, E.M. (1998). Târîh-i Beyhakî, I. (Feyyâz. thk.). Tahran: İntişârât-1 Hirmend.

Bosworth, C. E. (1984). Âl-e Farighûn. Encyclopaedia iranica, (C. 1, s. 756-758). Brill.

Bosworth, C. E. (1999). Târîh-i Gaznevîyân. (Enuşe. H., Çev.). Tahran: Müesses-i İntişârât-1 Emir Kebir. Davud, S. A. (2018). Farîghûnids. Encyclopaedia ıslamica online. (Wilferd. M., Farhad D. Çev). Brill.

Fazlullah, R. (2008). Câmiü't-Tevârîh. (Rûşen. M., tkh). Tahran: Miras-1 Mektub.

Gerdîzî, A. (1985). Zeynü'l-Ahbâr. (Habîbî. A., thk.). Tahran: İntişârât-1 Bünyad-ı Ferheng-i İran.

Gerdîzî, A. (2005). Zeynü'l-Ahbar. (Melik. R.R., thk.). Tahran: Encümen-i Âsâr ve Mefahir-i Ferhengi.

Gubar, G. M. (2005). Afganistan der mesir-i tarih. Kâbil: Benigâh-i İntişârât-ı Meyvend.

Habîbî, A. (2011). Coğrafyay-ı târîh-i Afganistan. Kâbil: Benigah-ı İntişârât-1 Meyvend.

Hatîb, A. M. (1959). Hükümet-i Benî Ümeyye der Horasan. (Musevî. B., Çev.). Tahran: İntişârât-1 Tûka.

Haug, R. (2015). "Farîghûnis". In Fleet, Kate; Krämer, Gudrun; Matringe, Denis; Nawas, John; Rowson, Everett (eds.). Encyclopaedia of ıslam, Brill.

Hümayun, N. T. (2004). Hârizm, Tahran: Defter-i Puizhişhay-1 Ferhengi.

Hüseyinî, L. Ş. (2020). Coğrafya-ı siyasi-i ve ferhengi-i Âl-i Ferîgûn. Tahran: İntişârât-1 Ümit Saba.

İbn Haldun, A. (2000). Târîh-i İbn Haldun, IV. (Şehade. H., Zekar. Süheyl. Thk.). Beyrut: Dârü'l-Fikr.

İbn Havkal, E. (1938). Kitâbü sûretü'l-arz, I-II. Beyrut: Dâr-1 Sadr, Beyrut.

İbnü'l-Esîr, İ. (2004). el-Kâmil fi't-târîh, XIII. (Âjir. H.R., Çev.). Tahran: İntişârât-1 Asâtir.

İbnü'l-Esîr, İ. (1987). el-Kâmil fi't-târîh, VIII. (Dukâke. M.Y., thk.). Beyrut: Dârü'l-Kütûbü'l-İlmiyye.

Kitapçı, Z. (2000). Arapların Türkistan'a girişi. İstanbul: Türk Dünyası Araştırmaları Vakfı.

Makdisî, M. (1991). Ahsanü't-tekâsim fì marifeti'l-ekalim. Kahire: Mektebetü Medbulî.

Munis, H. (1987). Atlasu Târihü'l-İslam. Kahire: Ez-Zehra Li'l-ïlâmü'l-Arabî.

Müstevfî, H. (1961). Târîh-i Güzide. (Nevaî. N., thk). Tahran: Emir Kebir.

Müverrihü'l-Mısrî, (2009). Dirasât ve buhûs fít-târîhiyye ve'l-hadariyye, Kısmü't-Târîh Külliyetü'l-Âdâb. Kahire: Câmiatü'l-Kahire.

Taberî. M. (1967). Târîhü't-Taberî Târîhü'r-Rusûl ve'l-Mülük, VI. Kahire: Dârü'l-Maarif-1 Misır.

Utbî, M. (1966). Tercüme-i Târîh-i Yemînî. (Curfadekânî. N., Çev.). (Şiâr. C., tsh.). Tahran: Tahran Üniversitesi Yayınları.

Vehbî, H. (1884). Meşâhir-i İslam, I. İstanbul: Mühran Matbaası.

Yazıcı, T. (1995). Ferîgûnîler. İslam anseklopedisi, (C. 7, s. 388-399). İstanbul: Diyanet Vakfı Yay.

Yazıcı, T. (1993). Cüzcân. İslam anseklopedisi, (C. 8, s. 96-97). İstanbul: Diyanet Vakfı Yay.

Zambawar, M. (1980). Mucemü'l-ensâb ve'l-üserâtü'l-hâkime fi't-târîh-i'l-islamî. (Bek. Z. M.H. Bek; Mahmud. H.A.). Beyrut: Dârü'r-Râid el-Arabî.

Zeki, İ. (2019). Gazneli Mahmud'un din politikası. Konya: Çizgi Kitabevi.

Zeki, İ. (2020). Horasan'da hâkimiyet mücadelesi (821-1005). Konya: Çizgi Kitabevi.

Zeki, İ. (2020). Illk dönem horasan valileri (621-821). Konya: Çizgi Kitabevi. 
EK

Ferîgunîlerin Seceresi (250-401806-1010)

Feriĝûn (250-279864-892)

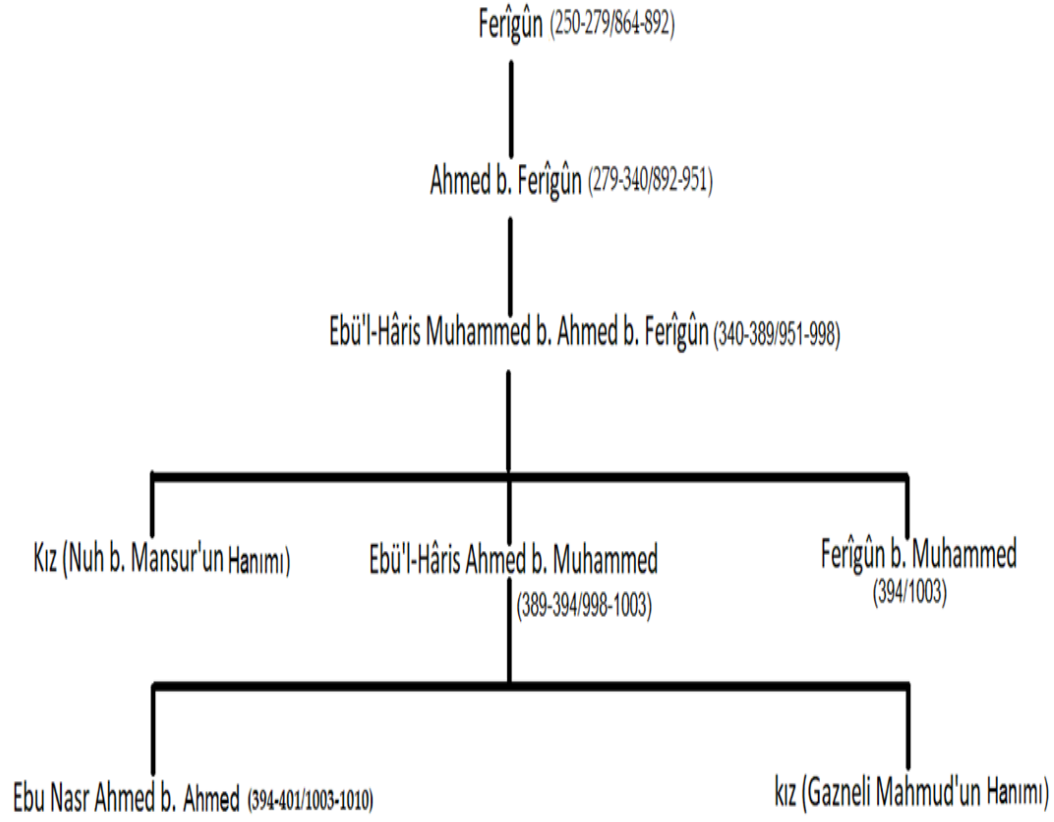

(Sebökikgegn'in kzzy) evili)

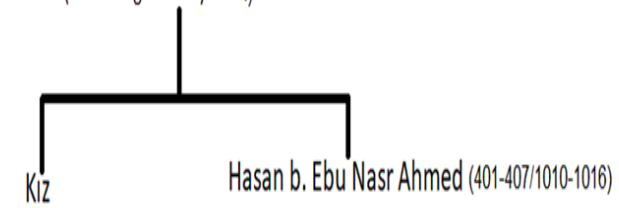

(Ebu Ahmed Muhammed b.

Gaznel Mahmud'un Hanimiı)

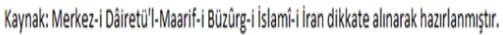

Ek I: Ferîgûnîlerin Şeceresi 